US experimental drug rule change may help biotechnology

\section{Washington}

Drug companies may now be able to sell, rather than provide free of charge, experimental drugs designed to treat serious or life-threatening diseases in advance of US Food and Drug Administration (FDA) approval, if proposed rule changes by FDA are adopted. This is one of the most controversial changes to the Investigational New Drug (IND) regulations, and could provide important benefits to small drug manufacturers.

The rule changes are the result of an investigation by the Presidential Task Force on Regulatory Relief, whose chief purpose was to give pharmaceutical companies increased incentives to develop and test new drugs for the treatment of serious diseases, particularly AIDS (acquired immune deficiency syndrome). Freedom to recoup a portion of drug development costs during clinical trials may be an important incentive: the cost of developing a new drug and taking it through clinical trials is estimated at $\$ 100$ million.

The proposed changes would permit a pharmaceutical company to charge for drugs administered to patients participating in clinical trials and to others eligible. But the drugs must have passed at least Phase I clinical trials, where safety to humans and dose amount is evaluated, and probably Phase II trials, where drug efficacy is tested. Drug companies would be prohibited from actively marketing the drug and would have to continue to work toward final FDA approval.

Only drugs being developed for the treatment of serious or life-threatening diseases would qualify under the proposed new regulations. Diseases such as Alzheimer's and multiple sclerosis would fall in the "serious" category, while AIDS, and certain uncontrollable cardiac arrhythmias, would be "life-threatening".

Before selling an experimental drug to patients in a clinical trial, a drug company would also have to convince FDA that the sale is needed for the sponsor to undertake or continue the trial. Companies would be able to sell drugs to patients not participating in clinical trials without restriction as long as the agreed protocol was followed.

Although the proposed regulation would benefit affected patients by stimulating innovations in drug development, it may also impose a financial hardship on them. Most health insurance companies will not pay for drug therapy not approved by the FDA. But a spokesman for the Health Insurance Association of America pointed out that if no other treatment is available, some companies might pay on a case-by-case basis. FDA has said that it will not allow excessively high prices for experimental drugs, and will withdraw its approval if the price for a drug is unfair.

The new ruling would have a very favourable effect on the biotechnology industry, and particularly on small companies, according to Richard Godown, president of the Industrial Biotechnology Association. The development of drugs produced by genetic engineering is especially costly. Several smaller companies have drugs in clinical trials that may qualify under the proposed regulations.
According to Jim McCamant, editor of the Medical Technology Stock Letter, anticancer drugs are likely candidates. Cetus has its tumour necrosis factor in Phase II trials, Ribi Immunochem has adjuvants for the treatment of a several cancers in Phase I and II trials and Xoma has immunotoxins to treat melanoma in Phase II tests. Genentech's tissue plasminogen activator (tPA) might also qualify, although it is expected to win FDA marketing approval soon.

Because of the controversy surrounding the proposed changes, FDA is accepting public comments until 20 April. If approved, companies could begin selling experimental drugs as early as 17 June this year.

Carol Ezzel

\title{
OTA gives Congress options on cell-line donor ownership
}

Washington

THE Office of Technology Assessment (OTA), the technology policy analysis arm of the US Congress, last week issued a report* intended to help Congress to clarify a now-fuzzy area of biotechnology - the ownership of human tissues and cells. The contents of the report could lead to new regulations and procedures for the collection and use of human tissues in research and product development.

There is at present no legislation expressly governing human cell and tissue culture. Although this has not been considered a problem in the past, rapid developments in biotechnology in the past several years using human products have caused concern. At issue is whether the original human donor should share in the commercial benefits to be reaped from techniques employing human cells, and the legal and ethical questions arising from selling human tissues. The technologies concerned are the development and maintenance of human cell lines, hybridomas for making monoclonal antibodies and recombinant DNA techniques such as gene probes.

Under the present system, the benefits of commercial products developed from human cell cultures are not shared with the person who donated the cells, who is usually not aware that his tissues have been put to commercial use. The tissues used in both basic research and the development of products from human cells are likely to be cast-offs from surgery. Clonetics Corporation, for example, uses human skin from elective plastic surgery as a source for its normal human epidermal cell cultures.

But the growth and manipulation of human cells is often described as more art than science. Human cells are fastidious in culture, and attempts to create immortal cell lines from non-tumour tissue are rarely successful on more than 1 per cent of occasions with some tissue types. In the case of sophisticated technology using human cells, such as the creation of hybridomas, it is the efforts of the researcher that make a profitable product.

Given these considerations, the question arises whether the human donor is entitled to a share in the profits. Industry researchers claim that it would be extremely tedious, and sometimes next to impossible, to trace the development of a commercial product back to its human source for the purpose of profit-sharing. Tissues and cell cultures are now freely exchanged between researchers.

The OTA report describes several options for Congress to explore in resolving these issues. If the ethical rules that determine compensation for human-tissue donations are deemed appropriate, Congress could enact procedures to force researchers to keep detailed records on the sources of tissues and cells. Donors could be reimbursed for the 'service' of donation, or could receive no compensation at all unless their donation resulted in the development of a profitable product. Conversely, Congress could rule that the ban on the sale of human organs by the National Organ Transplant Act extends to human tissues and cells, thus barring patients from recompense for tissue and cell donations.

Representative Robert A. Roe (Democrat, New Jersey), chairman of the Committee on Science, Space and Technology, has asked the Department of Health and Human Services to evaluate the options outlined by the OTA report regarding informing patients about the uses of their donated tissues.

Carol Ezzell

* New Developments in Biotechnology: Ownership of Human Tissues and Cells is available as OTA-BA-337 from the US Government Printing Office, Washington, DC. 